\title{
RNA binding protein Nova1 promotes tumor growth in vivo and its potential mechanism as an oncogene may due to its interaction with $\mathrm{GABA}_{\mathrm{A}}$ Receptor- $\mathrm{\gamma} 2$
}

\author{
Yi-An Zhang ${ }^{1+}$, Hai-Ning Liu ${ }^{2+}$, Ji-Min Zhu ${ }^{2}$, Dan-Ying Zhang ${ }^{2}$, Xi-Zhong Shen ${ }^{2,3}$ and Tao-Tao Liu ${ }^{2 *}$
}

\begin{abstract}
Background: The mechanism of Nova1's role in hepatocellular carcinoma has not been delineated. Also its interaction with $\mathrm{GABA}_{A}$ receptor $\mathrm{Y} 2$ in $\mathrm{HCC}$ is unveiled. This study is aimed to make it clear the distribution, prognostic value of GABA $R Y 2$ in human hepatocellular carcinoma. And its role in HCC tumorigenesis under the regulation of its alternative splicing factor Nova1.

Methods: Immunohistochemistry staining was used to investigate the distribution and clinical significance of

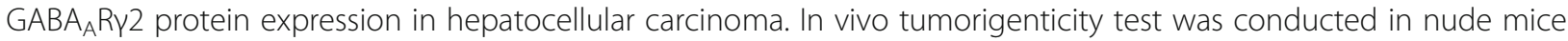
by regulation the expression of Nova1. Later, western blot and co-immunoprecipitation were carried out to verify the interaction between Nova1 and GABA $R$ RY2 in HCC tissue.

Results: Immunohistochemical staining showed $G_{A B A} R Y 2$ expression in HCC. Survival analysis showed intratumoral GABA ${ }_{A} R \gamma 2$ was an independent prognostic factor for overall survival (OS) and disease free survival (DFS). Up-regulation of Nova1 expression promotes subcutaneous HCC growth in nude mice and western blot showed the ectopic expression of Nova-1 restro-regulates the expression of GABA $R$ RY2 and GABA. Protein level interaction of $\mathrm{GABA}_{A} \mathrm{R} Y 2$ and Nova-1 was evidenced by co-immunoprecipitation.

Conclusions: Nova1 interacts with GABA $A_{A} R 2$ not only in CNS but also in HCC. Nova1's potential mechanism as an oncogene may due to its interaction with $\mathrm{GABA}_{A}$ Ry2. A better understanding of the mechanism of Nova1 for HCC progression provides a novel target for an optimal immunotherapy against this fatal malignancy.
\end{abstract}

Keywords: Nova1, GABA Receptor- $\gamma 2$, Oncogene, RNA binding protein

\section{Background}

Hepatocellular carcinoma (HCC) is the second leading cause of cancer-related deaths worldwide. Although large efforts have been made to have a deeper insight into its pathogenesis and treatment, it is still one of the few cancers with a continued increase in incidence observed over these decades [1].

\footnotetext{
*Correspondence: liu.taotao@zs-hospital.sh.cn

${ }^{\dagger}$ Equal contributors

${ }^{2}$ Department of Gastroenterology, Zhongshan Hospital of Fudan University, Zhongshan Hospital, No.180 Fenglin Road Xuhui District, Shanghai, China

Full list of author information is available at the end of the article
}

In recent years, the roles of RNA-binding proteins (RBPs) in the progression and prognosis of HCC have been delineate [2-4]. Nova-1, a neuron specific RNA binding protein, influences ligand-binding, signaltransducing and electrophysiological properties [5]. Our previous study demonstrated the expression of Nova-1 in HCC and proved that high expression of Nova-1 is associated with poor prognosis of HCC [6]. Previous researchers also found that Nova-1 regulates the alternative splicing of $\mathrm{GABA}_{\mathrm{A}}$ receptor $\gamma 2\left(\mathrm{GABA}_{\mathrm{A}} \mathrm{R} \gamma 2\right)$ premRNA in central nervous system [7]. $\mathrm{GABA}_{\mathrm{A}} \mathrm{R} \gamma 2$ belongs to the GABA receptor family. $\mathrm{GABA}_{\mathrm{A}}$ is most prevalent not only in central nervous system but also in peripheral tissues [8]. Activation of $\mathrm{GABA}_{\mathrm{A}}$ receptors 
resulted in increased chloride ion influx and hyperpolarization of cell membranes by diminishing the chance of a successful action potential occurring [8]. Recently, lots of reports have pointed out that the relationship between decreased hepatocyte membrane potential and proliferation of hepatocellular carcinoma. Related receptors include $\mathrm{GABA}_{\mathrm{A}}$ receptor- $\beta 3$ [9], $\mathrm{GABA}_{\mathrm{A}}$ receptor$\alpha 3$ [10], and $\mathrm{GABA}_{B}$ Receptor family [11]. However, the potential effects of $\mathrm{GABA}_{\mathrm{A}} \mathrm{R} \gamma 2$ on tumor proliferation has not been mentioned yet.

In this study we first conducted a tumorigenticity test in nude mice and found that Noval could improve tumor growth in vivo. The interaction between Nova1 and $\mathrm{GABA}_{\mathrm{A}} \mathrm{R} \gamma 2$ was further confirmed by coimmunoprecipitation. Later, verification of the $\mathrm{GABA}_{\mathrm{A}} \mathrm{R} \gamma 2$ expression in hepatocellular carcinoma and its relations with $\mathrm{HCC}$ prognosis were also investigated. After all we demonstrated that Nova1 could promote cell proliferation in vivo, its potential mechanism as an oncogene may related to its interaction with $\mathrm{GABA}_{\mathrm{A}} \mathrm{R} \gamma 2$, and suggested that Nova1 and $\mathrm{GABA}_{\mathrm{A}} \mathrm{R} \gamma 2$ could be a novel predictor for $\mathrm{HCC}$ recurrence after curative resection.

\section{Methods}

\section{Cells, animals and reagents}

Two human HCC cell lines were used in this study. SMMC7721, Huh7 were purchased from Shanghai Institute of Cell Biology, Chinese Academy of Sciences (Shanghai, China). SMMC7721 was cultured in RPMI medium 1640 (GIBCO, USA). Huh7 were cultured in DMEM supplemented with $10 \%$ fetal bovine serum (GIBCO, Austria). Cells were cultured and passaged in $37^{\circ} \mathrm{C}$ incubator with humidified atmosphere containing $5 \% \mathrm{CO}_{2}$. Protocols of the establishment of cell lines to induce the Nova1 expression or silencing was summarized in previous study [6]. BALB/c nude mice were purchased from Shanghai Experimental Animal Centre, Chinese Academy of Science. Experimental animals were kept in the central animal facility of the Zhongshan Hospital affiliated to Fudan University and housed in laminar-flow cabinets under specific pathogen-free conditions. All studies on mice were conducted in accordance with the National Institute Guide for the Care and Use of Laboratory Animal. Goat anti-human Nova1 polyclonal antibody was purchased from LifeSpan Biosciences (Seattle, USA). Rabbit anti-human $\mathrm{GABA}_{\mathrm{A}} \mathrm{R} \gamma 2$ antibody was from Millipore. Rabbit anti-human GABA antibody was from Abcam. HRP affinipure goat anti-rabbit antibody was purchased from EarthOx, LLC (San Francisco, USA). DyLight 448 Affinipure Rabbit Anti-Goat IgG and DyLight 594 Affinipure Goat Anti-Rabbit IgG were purchased from Jacson. Mouse anti-GAPDH antibody and HRP-labeled goat anti-mouse antibody were purchased from Beyotime Institute of Biotechnology (Shanghai,
China). ECL Western Blotting Substrate System was purchased from Pierce (Rockford, IL, USA).

\section{Patients and specimens}

Tissue microarrays used in this study were from Liver cancer institue, Zhongshan Hospital. (Shanghai Super Biotec company (ZL-LVC1604)). Eighty HCC patients who underwent curative resection, defined as complete macroscopic removal of the tumor, with clinicopathologic and follow-up data were inrolled in this study. None of the patients received anticancer therapy before sampling. The hepatocellular carcinoma diagnosis was established by history, physical examination, computer tomography, MRI (Magnetic Resonance Imaging), liver biopsy and subsequent histological and cytological analyses. Curative resection was defined as complete resection of tumor nodules and the surgical free margin of more than $5 \mathrm{~mm}$ by pathological examination; have no cancerous thrombus found in the portal vein(main trunk or two major branches), hepatic veins, or bile duct; and having no extra hepatic metastasis found.

All patients were followed every 3-4 months afterward. Most patients died of intrahepatic recurrence, distal metastasis, or complicated liver cirrhosis. All patients were monitored prospectively by serum AFP, abdomen ultrasonography (US), and chest X-ray every 1-6 months, according to the postoperative time. For patients with test results suggestive of recurrence, computed tomography (CT) and/or magnetic resonance and/or distal metastasis had occurred. Adiagnosis of recurrence was based on typical imaging appearance in $\mathrm{CT}$ and/or MRI scan and an elevated AFP level. Overall survival (OS) was defined as the interval between the dates of surgery and death. Disease-free survival (DFS) was defined as the interval between the dates of surgery and recurrence or the last follow-up if no recurrence was observed. Clinical stages of tumors were determined according to the TNM classification system of International Union Against Cancer (Edition 6). Tumor differentiation is grade according to Edmondson-Steiner classification.

\section{Ethics approval}

All samples were coded anonymously in accordance with local ethical guidelines, as stipulated by the Declaration fo Helsinki with written informed consent and a protocol approved by the Ethics Review Committee of Zhongshan Hospital of Fudan University, and every patient provided written informed consent before enrollment.

\section{In vivo tumorigeniticity}

The HCC tumor xenografts animal models were established as follow: $1 \times 10^{\wedge} 6$ Huh7 pSLIK empty vector, Huh7-shNova1 cells, SMMC7721 pSLIK empty vector 
and SMMC7721-Nova1 cells were inoculated subcutaneously into the right side backs of the nude mice. For the tet-on system [6], Huh7-shNova1 and SMMC7721Nova1 groups were further randomly divided into two groups, with (+Dox) or without (-Dox). (+Dox: Dox added into the mouse drinking water at a concentration of $1 \mathrm{mg} / \mathrm{ml}$.) After the injection, the tumor size was estimated according to the formula: volume $\left(\mathrm{mm}^{3}\right)=0.5 \mathrm{a}^{2} \times \mathrm{b}$ (a, major diameter of tumor; b, minor diameter perpendicular to the majour one). Animals were feed for 4 weeks and in the end of feeding, animals were sacrificed. The tumor were removed for western blot analysis.

\section{Immunochemical staining}

The dissected tumor samples for immunohistochemistry were fixed in phosphate-buffered neutral formalin, embedded in paraffin, and cut into 5 - $\mu \mathrm{m}$-thick sections. Fivemicron thick sections and tissue microarrays were fixed in $4 \%$ formaldehyde and embedded in paraffin. Tissue samples were deparaffinized and rehydrated, followed by hightemperature antigen retrieval via microwave in $0.1 \mathrm{M}$ citrate solution ( $\mathrm{pH} \mathrm{6.0)}$ for $15 \mathrm{~min}$. After blocked with $5 \%$ normal goat serum at room temperature for $30 \mathrm{~min}$, the sections were incubated with rabbit anti-human $\mathrm{GABA}_{\mathrm{A}} \mathrm{R} \gamma 2$ antibody at $4{ }^{\circ} \mathrm{C}$ overnight, and then incubated with appropriate secondary antibody at room temperature for $30 \mathrm{~min}$, and finally immunostained by avidin-biotin complex technique using 3,3'-diaminobenzidine. Hematoxylin was used as a counterstain.

The total amount of positive cells in each section was evaluated by two independent investigators masked to clinical outcome and clinicopathologic data. Positive staining cells were observed by using one light microscope (Olympus BX51, Japan). The Friedrichs scoring system was applied to analyze expression of in tumor and peritumor tissues. The intensity of $\mathrm{GABA}_{\mathrm{A}} \mathrm{R} \gamma 2$ staining was divided into four grades, score "0" for negative, " 1 " for light yellow, "2" for deep yellow, "3" for brown. $\mathrm{GABA}_{\mathrm{A}} \mathrm{R} \gamma 2$ staining positive cells was further subgrouped into score "0" for less than $5 \%$, "1" for 6-20\%, "2" for 21$50 \%$ and " 3 " for more than $51 \%$. The total score was defined as staining intensity and scales. Total score higher than 2 is considered as high expression, while under 2 as low expression.

\section{Western blotting}

Total cell or tissue lysates were generated and equal amount protein was subjected to $10 \%$ SDS-PAGE gel, and then transferred onto polyvinylidene difluoride (PVDF) membranes (Millipore, Bedford, USA). Membranes were blocked in blocking solution $(50 \mathrm{mM}$ Tri-HCl, $150 \mathrm{mM} \mathrm{NaCl}, 5 \%$ (w/v) non-fat dry milk and $0.1 \%$ Tween-20) at room temperature for $1 \mathrm{~h}$, followed by incubation with Rabbit anti-human $\mathrm{GABA}_{\mathrm{A}} \mathrm{R} \gamma 2$ antibody and rabbit anti-human GABA antibody at $4{ }^{\circ} \mathrm{C}$ overnight. After three times washing by $0.1 \%$ TBSTween20, the membrane was incubated with secondary antibody at room temperature for $1.5 \mathrm{~h}$, the blot were demonstrated by enzyme-linked chemiluminescence using a Fluor Chem FC2 chemilumilescent, fluorescent and visible light gel imaging system (Alpha Inotech, USA).

\section{Co-immunoprecipitation (co-IP)}

The cell-lysated proteins were precleared with $2 \mu \mathrm{g}$ appropriate antibodies at $4{ }^{\circ} \mathrm{C}$ for $8 \mathrm{~h}$, and then incubated with protein G-agarose (Roche) and antibodies at $4{ }^{\circ} \mathrm{C}$ overnight. For co-IP experiments using anti-Ub antibody, the cell lysates contained $1 \%$ SDS and received prior heat treatment. The precipitates were pelleted, washed three times with the lysis buffer and analyzed by western blotting.

\section{Statistical analysis}

All values were expressed as mean \pm standard deviation (SD). All statistical analyses were performed using the SPSS 18.0 (SPSS Inc., Chicago, IL). $\chi^{2}$-test or Fisher's exact tests was used for the association of $\mathrm{GABA}_{\mathrm{A}} \mathrm{R} \gamma 2$ expression with the clinicopathologic features. Student's $t$ test and independent sample $t$ test were used for comparison between groups. Cumulative survival time was calculated by kaplan-Meier method and analyzed by the log-rank test. Univariate and multivariate analyses were based on the Cox proportional hazard regression model. $P<0.05$ considered as statistically significant.

\section{Results}

\section{Nova1 promotes tumor growth in vivo}

As shown in Fig. 1, for Huh7-shNova1, tumor volumes in + Dox group were smaller than that in -Dox group $(31.25 \pm 15.90 \mathrm{~mm} 3$ vs. $287.10 \pm 51.10 \mathrm{~mm} 3, P<0.05)$. While for SMMC7721, the results showed that tumor of + Dox group grew faster and larger than -Dox (418.9 \pm $185.6 \mathrm{~mm} 3$ vs. $107.7 \pm 78.83 \mathrm{~mm} 3, P<0.01)$. These data indicated that Dox-induced Noval expression promotes subcutaneous HCC growth significantly (Fig. 1a-c).

\section{Expression of $\mathrm{GABA}_{\mathrm{A}} \mathrm{R} Y 2$ and $\mathrm{GABA}$ in hepatocellular carcinoma under the regulation of ectopic Nova-1}

Later, immunohistochemical staining and western blot were carried out on tumor biopsy of nude mice. Study showed that down-regulation of Nova-1 accompanied with increased expression of $\mathrm{GABA}_{\mathrm{A}} \mathrm{R} \gamma 2$ and GABA (Fig. 1d-e). The ectopic expression of Nova-1 restroregulates the expression of $\mathrm{GABA}_{\mathrm{A}} \mathrm{R} \gamma 2$ and GABA. 


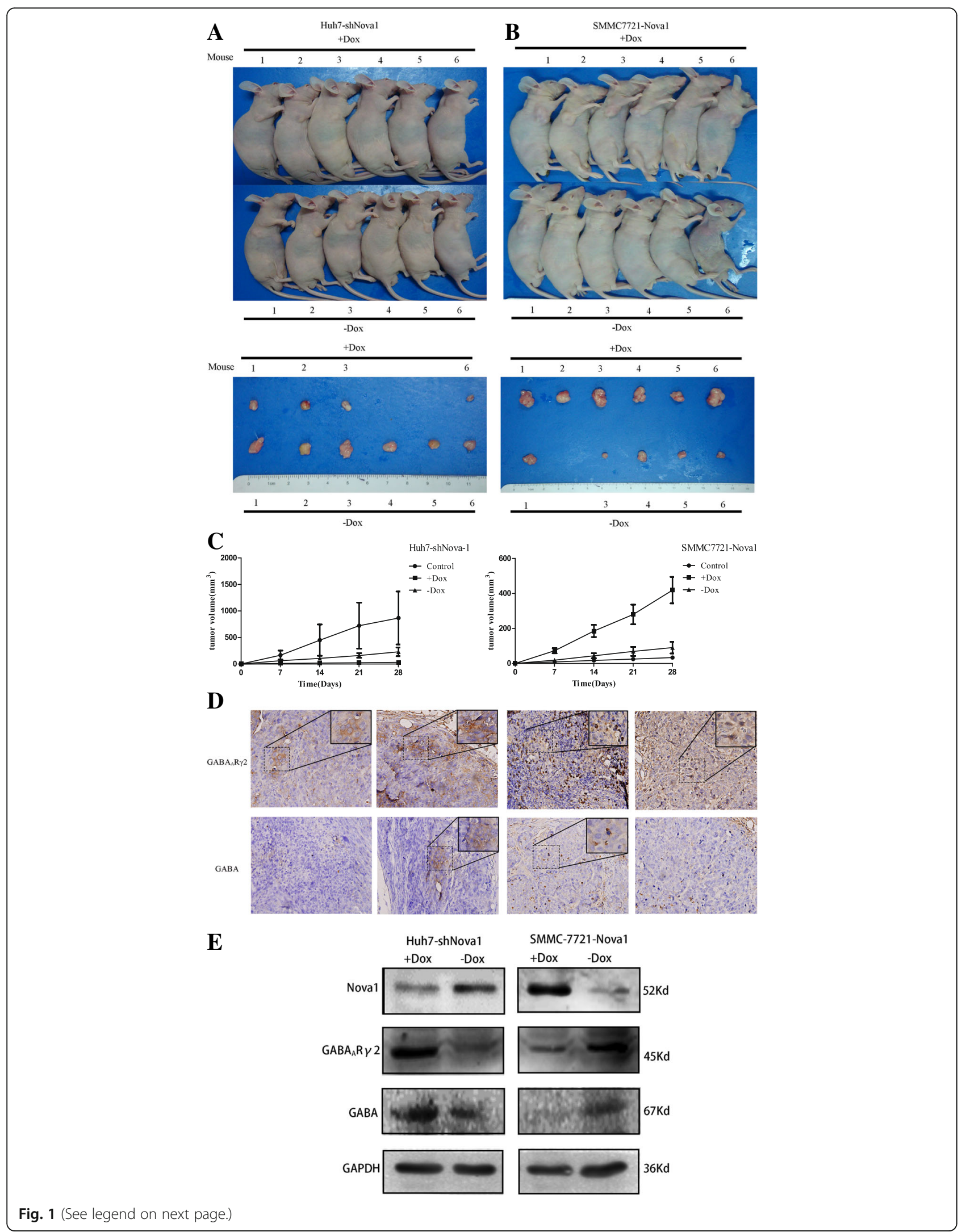


(See figure on previous page.)

Fig. 1 Nova1 promotes tumor growth in vivo and the expression of GABA $R$ Ry2 in tumor tissue is restro-regulated by Nova1. Photography of in vivo tumorigeniticity of Huh7-shNova1 (a) and SMMC7721-Nova1 (b). c Growth kinetics of tumor volumn in nude mice. Tumor diameters were measured every 7 days. $\mathbf{d}$ Representative photographs of immunohistochemical analysis of GABA $A R Y 2$ and GABA antigens in tumors of nude mice (original magnification: $\times 200$; upper right coner, $\times 400$ ). e Western blot of the expression of GABA $R \gamma 2$ and GABA in tumors of nude mice under the regulation by overexpression or down-regulation the expression of Nova1

\section{$\mathrm{GABA}_{\mathrm{A}} \mathrm{R}$ 2 2 interacts with Nova-1 in peripheral tumor tissues}

Co-IP was used to verify the possibility of $\mathrm{GABA}_{\mathrm{A}} \mathrm{R} \gamma 2$ interacts with Nova1 outside the CNS in protein level. In Huh-7 cells, GABA $\mathrm{R} \gamma 2$ was easy to be detected through anti-Nova-1 antibody. Reciprocal co-IP experiments using anti-GABA $\mathrm{R} \gamma 2$ antibody indicated the existence of Nova-1. To verify the stringency of co-IP, parallel expreiments were done in which co-IP antibody was replaced with isotype control antibody IgG or PBS. Meanwhile, control experiments showed negative results (Fig. 2).

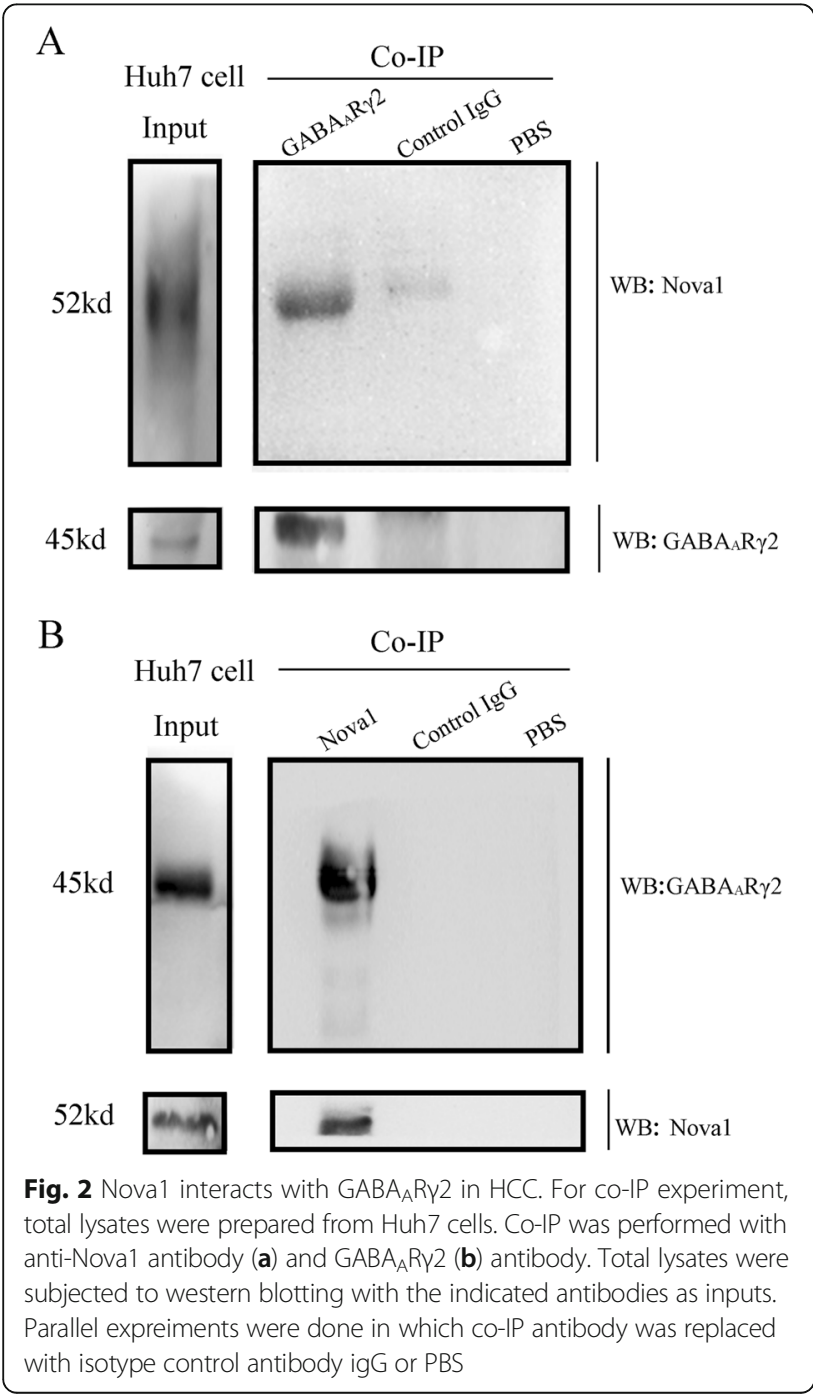

\section{Expression level of $\mathrm{GABA}_{A} \mathrm{R} \gamma 2$ in $\mathrm{HCC}$ patients and its clinical significance}

To explore the occurrence of $\mathrm{GABA}_{\mathrm{A}} \mathrm{R} \gamma 2$ expression in $\mathrm{HCC}$, we first detected $\mathrm{GABA}_{\mathrm{A}} \mathrm{R} \gamma 2$ protein levels in tumor and peritumoral tissues. $\mathrm{GABA}_{\mathrm{A}} \mathrm{R} \gamma 2$ shows a mainly cytoplasmic staining on various normal liver cells and cancer cells (Fig. 3a). The percentage of $\mathrm{GABA}_{\mathrm{A}} \mathrm{R} \gamma 2$ positivity in the cancerous tissues was lower than that of para-cancerous tissues $(35 \%, 28 / 80$ vs. $57.5 \%, 46 / 80$ respectively, $P=0.004)$. As shown in Table 1 , clinicopathologic variables such as vascular invasion $(P=0.014)$, tumor number $(P=0.016)$ and TNM $(P=0.008)$ stage were found to be associated with expression levels of intratumoral $\mathrm{GABA}_{\mathrm{A}} \mathrm{R} \gamma 2$ expression. None of the clinicopathologic variables were associated with peritumoral $\mathrm{GABA}_{\mathrm{A}} \mathrm{R} \gamma 2$ expression.

On univariate analysis of our data, several clinical factors including liver cirrhosis, vascular invasion, TNM stage and BCLC stage, showed prognostic significance for both OS and DFS (Table 2). Notably, intratumoral $\mathrm{GABA}_{\mathrm{A}} \mathrm{R} \gamma 2$ expression was a favorable predictor for OS and DFS $(\mathrm{HR}=0.372$ and 0.419 , respectively, $P<0.01)$. Clinicopathologic features showing significance by univariate analysis were adopted for further multivariate cox proportional hazards analyses (Table 3). Liver cirrhosis, Barcelona clinic liver cancer $(\mathrm{BCLC})$ stage and intratumoral $\mathrm{GABA}_{\mathrm{A}} \mathrm{R} \gamma 2$ expression remained associated with $\mathrm{OS}(P=, 0.01$ and $<0.001$ respectively) while Liver cirrhosis,TNM stage and intratumoral $\mathrm{GABA}_{\mathrm{A}} \mathrm{R} \gamma 2$ expression remained associated with DFS $(P=0.007,0.035$ and 0.002 , respectively).

Since statistic results showed intratumoral $\mathrm{GABA}_{\mathrm{A}} \mathrm{R} \gamma 2$ was favorable predictor for recurrence, we then analyze this biomarker for early recurrence (metastasis after surgery $\leq 24$ months) together with other clinical feathers that showed prognostic significance for TTR (Table 4). Liver cirrhosis and intratumoral $\mathrm{GABA}_{\mathrm{A}} \mathrm{R} \gamma 2$ expression were found to be an independent predictor for early recurrence $(P=0.046$ and 0.01$)$.

Kaplan-Meier analysis and the log-rank test were performed to evaluate the effect of $\mathrm{GABA}_{\mathrm{A}} \mathrm{R} \gamma 2$ on survaival (Fig. 3b). Patients with higher intratumoral $\mathrm{GABA}_{\mathrm{A}} \mathrm{R} \gamma 2$ expression had significantly longer OS (median 46, months) or DFS (median, 36, months) than patients with lower intratumoral $\mathrm{GABA}_{\mathrm{A}} \mathrm{R} \gamma 2$ expression. (median, OS: 14 months;DFS: 10 months, $P=0.001$ and 0.002 respectively). Peritumoral $\mathrm{GABA}_{\mathrm{A}} \mathrm{R} \gamma 2$ was not associated with OS or DFS $(P>0.05)$. 


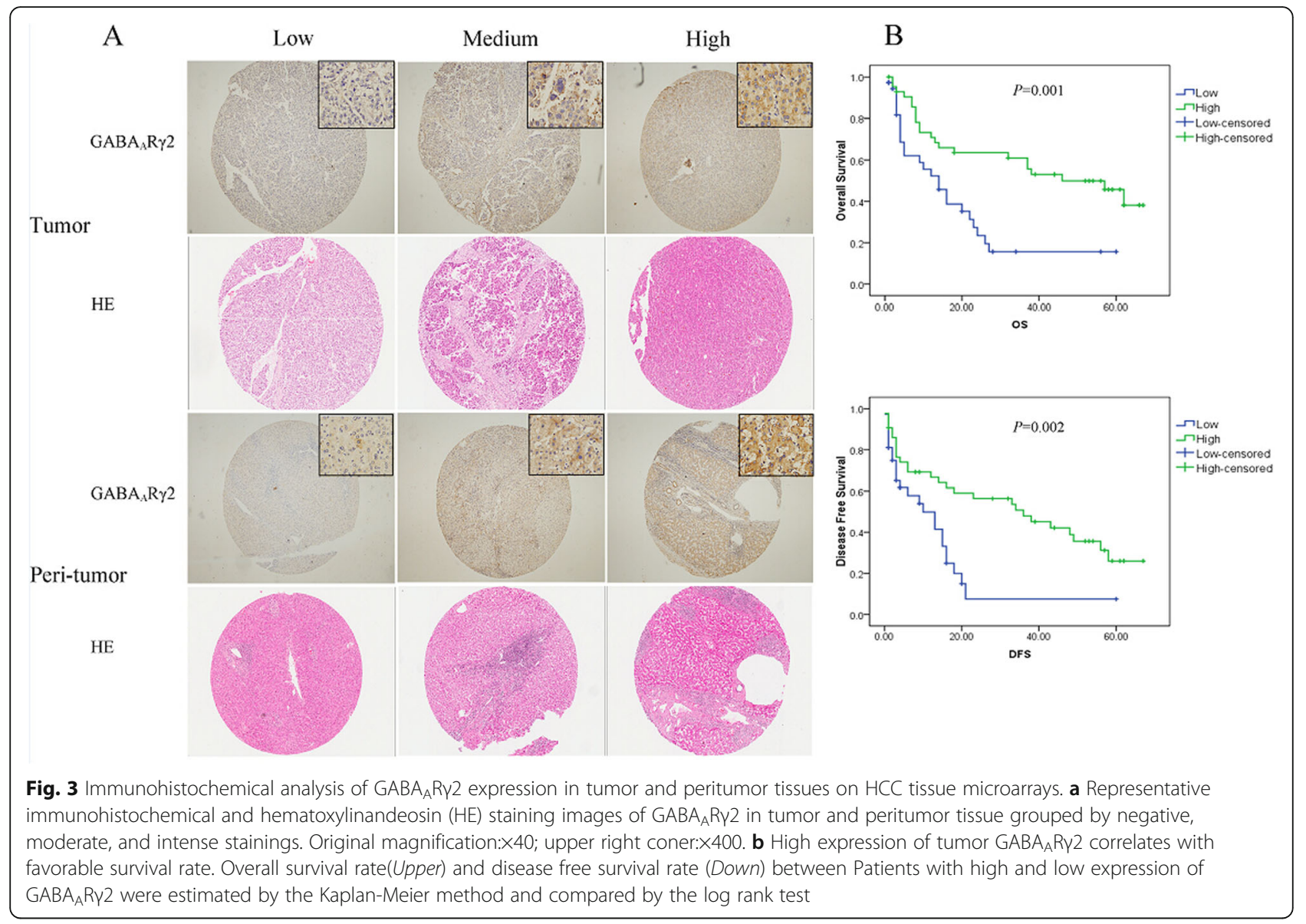

\section{Discussion and conclusions}

The $\mathrm{GABA}_{\mathrm{A}}$ receptor is an ionotropic receptor whose endogenous ligand is GABA, an inhibitory neurotransmitter in the central nervous system [12, 13]. By activation, the $\mathrm{GABA}_{\mathrm{A}}$ receptor selectively conducts chloride ion influx through its pore, leading to hyperpolarization of the neuron, thus causing an inhibitory effect on neurotransmission $[14,15]$. In humans, subunits of $\mathrm{GABA}_{\mathrm{A}}$ receptor include six types $\alpha$ subunits $(\alpha 1-\alpha 6)$, three $\beta s(\beta 1-\beta 3)$, three $\gamma \mathrm{s}(\gamma 1-\gamma 3)$, a $\delta$, a $\varepsilon$, a $\theta$ and a $\pi$ [16]. $\mathrm{GABA}_{\mathrm{A}}$ receptors are most prevalent not only in central nervous system but also in peripheral tissues [8]. By studying the relationship between decreased hepatocyte membrane potential and proliferation of hepatocellular carcinoma, the expression of some receptors in the peripheral tumor such as $\mathrm{GABA}_{\mathrm{A}}$ receptor- $\beta 3$ [9], $\mathrm{GABA}_{\mathrm{A}}$ receptor- $\alpha 3$ [10], and $G_{A B A_{B}}$ Receptor family [11] were found to correlate with tumor growth. $\mathrm{GABA}_{\mathrm{A}} \mathrm{R} \gamma 2$ belongs to the GABA receptor family, however, among all these studies, the potential effects of $\mathrm{GABA}_{\mathrm{A}} \mathrm{R} \gamma 2$ on tumor proliferation has not been mentioned yet.

In the present study, we found that $\mathrm{GABA}_{\mathrm{A}} \mathrm{R} \gamma 2$ is expressed mainly in cytoplasm and little in nuclear of
HCC by immunohistochemical staining. These findings corresponded with previous several reports proved the expression of $\mathrm{GABA}_{\mathrm{A}}$ receptors in peripheral tumor tissues, such as receptor $\alpha 2, \beta 1, \beta 3$ and $\gamma 3$ in human gastric cancer cell KATO III [17], receptor $\varepsilon$ and $\pi$ in human liver cancer tissue [9]. The expression of $\mathrm{GABA}_{\mathrm{A}} \mathrm{R} \gamma 2$ in tumor tissue is lower than that in paired peritumoral tissues which also be consistent with the research by Gerald Y. Minuk et al. [9]. By quantitative reverse transcription polymerase chain reaction (qRTPCR), they found that $\mathrm{GABA}_{\mathrm{A}}-\beta 3$ mRNA expression was decreased in tumor compared with adjacent nontumor tissue [9]. These two findings support previous descriptions of down-regulated or absent expression of $\mathrm{GABA}_{\mathrm{A}}$ receptor in human malignant hepatocyte cell lines and $\mathrm{GABA}_{\mathrm{A}}$ receptor $\beta 3$ subunit expression inversely correlated with regenerative activity of human and rat liver [18, 19]. According to our previous study [6], we suppose that the potential mechanism of Nova1 as an oncogene for HCC may due to its interaction with $\mathrm{GABA}_{\mathrm{A}}$ receptor $\gamma 2$.

Before that, Dredge et al. found the splicing regulation of the $\mathrm{GABA}_{\mathrm{A}} \mathrm{R} \gamma 2$ subunit pre-mRNA exon E9 is 
Table 1 Intratumoral and Peritumoral GABA $A$ RY2 expression according to characteristics of HCC patients

\begin{tabular}{|c|c|c|c|c|c|c|c|}
\hline \multirow[t]{3}{*}{ Characteristics } & & \multicolumn{3}{|c|}{ Intratumoral GABAARy2 } & \multicolumn{3}{|c|}{ peritumoral GABAARY2 } \\
\hline & & \multirow{2}{*}{$\begin{array}{l}\text { low } \\
n=52\end{array}$} & high & \multirow[t]{2}{*}{$p$ values } & \multirow{2}{*}{$\begin{array}{l}\text { low } \\
n=34\end{array}$} & \multirow{2}{*}{$\begin{array}{l}\text { high } \\
n=46\end{array}$} & \multirow[t]{2}{*}{$p$ values } \\
\hline & & & $n=28$ & & & & \\
\hline \multirow[t]{2}{*}{ Gender } & Male & 44 & 24 & 0.896 & 29 & 39 & 0.949 \\
\hline & Female & 8 & 4 & & 5 & 7 & \\
\hline \multirow[t]{2}{*}{ Age(years) } & $\leq 53$ & 33 & 14 & 0.243 & 20 & 17 & 0.991 \\
\hline & $>53$ & 19 & 14 & & 14 & 29 & \\
\hline \multirow{2}{*}{ Preoperative AFP(ng/ml) } & $\leq 20$ & 15 & 14 & 0.06 & 11 & 18 & 0.533 \\
\hline & $>20$ & 37 & 14 & & 23 & 28 & \\
\hline \multirow[t]{2}{*}{$\mathrm{HBsAg}$} & Negtive & 11 & 10 & 0.158 & 7 & 14 & 0.322 \\
\hline & Positive & 41 & 18 & & 27 & 32 & \\
\hline \multirow[t]{2}{*}{ Cirrhosis } & No & 2 & 4 & $0.176^{\mathrm{a}}$ & 2 & 4 & $1.000^{\mathrm{a}}$ \\
\hline & Yes & 50 & 24 & & 32 & 42 & \\
\hline \multirow[t]{2}{*}{ Vascular invasion } & No & 12 & 14 & 0.014 & 7 & 19 & 0.051 \\
\hline & Yes & 40 & 14 & & 27 & 27 & \\
\hline \multirow[t]{2}{*}{ Number } & Single & 36 & 26 & 0.016 & 25 & 37 & 0.465 \\
\hline & Multiple & 16 & 2 & & 9 & 9 & \\
\hline \multirow[t]{2}{*}{ Size $(\mathrm{cm})$} & $<5$ & 16 & 13 & 0.165 & 12 & 16 & 0.962 \\
\hline & $\geq 5$ & 36 & 15 & & 22 & 30 & \\
\hline \multirow[t]{2}{*}{ Tumor Differentiation } & $|-| \mid$ & 7 & 4 & $1.000^{\mathrm{a}}$ & 4 & 7 & 0.751 \\
\hline & III-IV & 45 & 24 & & 30 & 39 & \\
\hline \multirow[t]{2}{*}{ TNM stage } & I & 11 & 14 & 0.008 & 7 & 18 & 0.077 \\
\hline & $\|-\| \|$ & 41 & 14 & & 27 & 28 & \\
\hline \multirow[t]{2}{*}{ BCLC stage } & A & 5 & 6 & 0.18 & 3 & 8 & 0.338 \\
\hline & $\mathrm{B} / \mathrm{C}$ & 47 & 22 & & 31 & 38 & \\
\hline
\end{tabular}

${ }^{a}$ Fisher's exact test: $\chi 2$ for all other analyses

Table 2 Univariate analyses of factors associated with survival and recurrence

\begin{tabular}{|c|c|c|c|c|}
\hline \multirow[t]{2}{*}{ Variables } & \multicolumn{2}{|l|}{ OS } & \multicolumn{2}{|l|}{ DFS } \\
\hline & Hazard ratio $(95 \% \mathrm{Cl})$ & $P$ & Hazard ratio $(95 \% \mathrm{Cl})$ & $P$ \\
\hline Sex(male vs female) & $1.126(0.525-2.416)$ & 0.76 & $1.483(0.844-2.608)$ & 0.171 \\
\hline $\operatorname{Age}, y(\geq 53$ vs. <53) & $1.609(0.902-2.874)$ & 0.107 & $0.802(0.361-1.781)$ & 0.588 \\
\hline Preoperative AFP, ng/ml (>20 vs. $\leq 20$ ) & $1.320(0.721-2.415)$ & 0.369 & $1.390(0.778-2.485)$ & 0.266 \\
\hline HBsAg (negative vs.positive) & $1.175(0.598-2.311)$ & 0.639 & $1.040(0.563-1.925)$ & 0.899 \\
\hline Liver cirrhosis (yes vs. no) & $3.303(1.290-8.455)$ & 0.013 & $2.878(1.121-7.385)$ & 0.028 \\
\hline Vascular invasion (yes vs. no) & $1.976(1.004-3.891)$ & 0.049 & $0.922(0.523-1.625)$ & 0.78 \\
\hline Tumor size, $\mathrm{cm}(>5$ vs. $\leq 5)$ & $1.107(0.609-2.014)$ & 0.738 & $0.818(0.468-1.429)$ & 0.48 \\
\hline Tumor number (multiple vs.single) & $1.718(0.886-3.330)$ & 0.109 & $1.265(0.646-2.475)$ & 0.493 \\
\hline Tumor differentiation (I-II vs.|II-IV) & $1.215(0.566-2.608)$ & 0.618 & $0.971(0.472-1.999)$ & 0.937 \\
\hline TNM stage (III vs.I-II) & $2.253(1.209-4.199)$ & 0.011 & $2.137(1.177-3.880)$ & 0.013 \\
\hline BCLC stage (C vs. A/B) & $1.976(1.004-3.891)$ & 0.049 & $0.922(0.523-1.625)$ & 0.78 \\
\hline Intratumoral GABA ${ }_{A} R Y 2$ (high vs.low) & $0.372(0.203-0.683)$ & 0.001 & $0.419(0.232-0.755)$ & 0.004 \\
\hline Peritumoral $G A B A_{A} R \gamma 2$ (high vs.low) & $1.302(0.719-2.355)$ & 0.384 & $1.503(0.850-2.657)$ & 0.161 \\
\hline
\end{tabular}


Table 3 Multivariate analyses of factors associated with OS and DFS

\begin{tabular}{lll}
\hline & Hazard ratio $(95 \% \mathrm{Cl})$ & $P$ \\
\hline OS & & \\
Liver cirrhosis (yes vs. no) & $3.711(1.448-9.510)$ & 0.006 \\
Vascular invasion (yes vs.no) & & NS \\
TNM stage (II-III vs. I) & & NS \\
BCLC stage (B/C vs. A) & $2.591(1.251-5.365)$ & 0.01 \\
Intratumoral GABAARy2 (high vs.low) & $0.309(0.163-0.588)$ & $<0.001$ \\
DFS & & \\
Liver cirrhosis (no vs.yes) & $3.334(1.386-8.020)$ & 0.007 \\
TNM stage (II-III vs. I) & $2.009(1.050-3.844)$ & 0.035 \\
Intratumoral GABAARy2 (high vs.low) & $0.351(0.183-0.647)$ & 0.002 \\
\hline
\end{tabular}

disrupted in mice lacking Nova1 [7]. Transfection of pNova1-plasmid caused a dose-dependent increase in E9 inclusion in $293 \mathrm{~T}$ cells [7]. In CNS, the interaction between Nova1 and $\mathrm{GABA}_{\mathrm{A}} \mathrm{R} \gamma 2$ is delineated in the way that Nova1 acts directly on $\mathrm{GABA}_{\mathrm{A}} \mathrm{R} \gamma 2$ pre-mRNA by a direct action on clustered YCAY ( $\mathrm{Y}$ is a pyrimidine) intonic repeats [7]. In our study, Co-IP experiments proved the protein level interaction between $\mathrm{GABA}_{\mathrm{A}} \mathrm{R} \gamma 2$ and Nova1 in HCC. Furthermore, western blot showed down-regulation of Noval accompanied with increased expression of $\mathrm{GABA}_{\mathrm{A}} \mathrm{R} \gamma 2$ and GABA. The ectopic expression of Nova1 restro-regulates the expression of $\mathrm{GABA}_{\mathrm{A}} \mathrm{R} \gamma 2$ and GABA. It is unclear why upregulation of Nova1 did not turn out to be an increase expression of $\mathrm{GABA}_{\mathrm{A}} \mathrm{R} \gamma 2$ in tumor tissue, but restro-regulates the expression of $G_{A B A} R \gamma 2$ instead. Some mechanisms could partly explain the reason. (1) Dredge et al. found that Noval binds with high affinity to the wild-type but not the mutated sequence. Maybe the mutation of these YCAY repeats to YAAY in HCC completely abolished Noval's effect on splicing thus leading to the decrease expression of $\mathrm{GABA}_{\mathrm{A}} \mathrm{R} \gamma 2$ [20, 21]. (2) Gerald Y. Minuk et al. [9] found that the methylation status of $\mathrm{GABA}_{\mathrm{A}}$ receptor $\beta 3$ promoter in $\mathrm{HCC}$ resulted in attenuated downstream $\mathrm{GABA}_{\mathrm{A}}$ receptor $\beta 3$ gene expression. Therefore, the change of the methylation status of the upstream $\mathrm{GABA}_{\mathrm{A}} \mathrm{R} \gamma 2$ promoter in HCC may also exist. (3) Another view point proposed by Buckanovich et al. is that the interference with the RNA-binding activity of Noval may be an immune-mediated rather than the genetic mechanisms. Auto-antibodies due to ectopic expression of Nova1 protein abrogate the Nova-1-RNA interaction via immune-mediated mechanism leading to down-regulaiton of $\mathrm{GABA}_{\mathrm{A}} \mathrm{R} \gamma 2$ [20]. Since no futher evidence to prove the existence of muation sequence, nor further analysis of the $\mathrm{GABA}_{\mathrm{A}} \mathrm{R} \gamma 2$ promoter methylation in $\mathrm{HCC}$, nor experiments had been carried out to test the abrogation of auto-antibody of Nova1, additional studies to elucidate the mechanisms involved is needed.

Survival analyses showed that univariate and multivariate analysis disclosed the relationship of intratumoral $\mathrm{GABA}_{\mathrm{A}} \mathrm{R} \gamma 2$ and OS or DFS in HCC patients that intratumoral $\mathrm{GABA}_{\mathrm{A}} \mathrm{R} \gamma 2$ was an independent prognostic factor for OS and DFS. Moreover, intratumoral $\mathrm{GABA}_{\mathrm{A}} \mathrm{R} \gamma 2$ strongly correlated to $\mathrm{HCC}$ early recurrence. Some recognized factors such as BCLC stage, TNM stage vascular invasion were not associated with early recurrence, mostly likely because of the limited number of patients enrolled in the study. More HCC patients and longer follow-up study are still requied to verify our results in future study.

In conclusion, we demonstrated an decreased expression of $\mathrm{GABA}_{\mathrm{A}} \mathrm{R} \gamma 2$ in $\mathrm{HCC}$ compaired to adjacent normal tissue. Intratumoral $\mathrm{GABA}_{\mathrm{A}} \mathrm{R} \gamma 2$ was an independent prognostic factor for OS and DFS. Nova1 interacts with $\mathrm{GABA}_{\mathrm{A}} \mathrm{R} \gamma 2$ not only in CNS but also in HCC. Over-expression of Nova1 restro-regulates the expression of $\mathrm{GABA}_{\mathrm{A}} \mathrm{R} \gamma 2$ in HCC. Nova1 promotes tumor growth in vivo and its potential mechanism as an oncogene may due to its interaction with $\mathrm{GABA}_{\mathrm{A}}$ Receptor $\gamma 2$. A better understanding of the mechanism of RBP Noval for HCC progression might facilitate the design of more effective immunotherapies or gene therapy for hepatocellular carcinoma.

Table 4 Prognostic factors for early recurrence

\begin{tabular}{|c|c|c|c|}
\hline \multirow[t]{3}{*}{ Factor } & \multicolumn{2}{|c|}{ Early recurrence } & \multirow[b]{3}{*}{$P$} \\
\hline & Univariate & Multivariate & \\
\hline & $P$ & $\mathrm{HR}(95 \% \mathrm{Cl})$ & \\
\hline Liver cirrhosis (yes vs. no) & 0.039 & $2.610(1.016-6.706)$ & 0.046 \\
\hline Vascular invasion (yes vs.no) & 0.197 & & NS \\
\hline TNM stage (II-III vs. I) & 0.011 & & NS \\
\hline BCLC stage (B/C vs. A) & 0.197 & & NS \\
\hline Intratumoral GABA ${ }_{A} R Y 2$ (high vs.low) & 0.022 & $0.41(0.208-0.811)$ & 0.01 \\
\hline Peritumoral GABA ${ }_{A}$ Ry2 (High vs. Low) & 0.087 & & NS \\
\hline
\end{tabular}




\section{Abbreviations}

AFP: Alpha fetoprotein; BCLC: Barcelona clinic liver cancer; Cl: Confidence interval; CNS: Central nervous system; DFS: Disease free survival; GABA $A_{A}$ $\gamma$-aminobutyric acid ${ }_{A} ; G_{B B A} R \gamma 2: G A B A_{A}$ Receptor- $\gamma 2 ;$ HCC: Hepatocellular carcinoma; NS: Not significant; OS: Overall survival; PBS: Phosphate-buffered saline; qRT-PCR: Quantitative reverse transcription polymerase chain reaction; RBP: RNA-binding proteins; TNM: Tumor-node-metastasis; TTR: Time to recurrence

\section{Acknowledgments}

The authors would like to thank the members of Prof. Xizhong Shen's Laboratory for their helpful discussion and critical reading of the manuscript.

\section{Funding}

This study was supported by National Nature Science Foundation of China (No.81000968; No. 81101540; No. 81101637; No. 81172273; No. 81272388; No. 81301820, No. 81472673), Doctoral Fund of Ministry of Education of China (20120071110058), The National Clinical Key Special Subject of China.

\section{Availability of data and materials}

All relevant data are within the paper.

\section{Authors' contributions}

All authors read and approved the final manuscript.

\section{Competing interests}

YAZ, HNL, JMZ, DYZ performed experiments described in this study. XZS, TTL contributed to experimental design. YAZ, HNL contributed to manuscript writing. The authors declare that they have no competing interests.

\section{Consent for publication}

Not applicable.

\section{Ethics approval and consent to participate}

All samples were coded anonymously in accordance with local ethical guidelines, as stipulated by the Declaration fo Helsinki with written informed consent and a protocol approved by the Ethics Review Committee of Zhongshan Hospital of Fudan University with the following reference number Y2016-151, and every patient provided written informed consent before enrollment.

\section{Author details}

'Department of Hematology, Zhongshan Hospital of Fudan University, Zhongshan Hospital, No.180 Fenglin Road Xuhui District, Shanghai, China. 2Department of Gastroenterology, Zhongshan Hospital of Fudan University, Zhongshan Hospital, No.180 Fenglin Road Xuhui District, Shanghai, China. ${ }^{3}$ Key Laboratory of Medical Molecule Virology, Ministry of Education and Health, Shanghai Institute of Liver Diseases, Zhongshan Hospital, No.180 Fenglin Road Xuhui District, Shanghai, China.

Received: 9 June 2016 Accepted: 27 September 2016

Published online: 12 October 2016

\section{References}

1. Maluccio M, Covey A. Recent progress in understanding, diagnosing, and treating hepatocellular carcinoma[J]. CA Cancer J Clin. 2012;62(6):394-9.

2. Jeng YM, Chang CC, Hu FC, Chou HY, Kao HL, Wang TH, Hsu HC. RNAbinding protein insulin-like growth factor II mRNA-binding protein 3 expression promotes tumor invasion and predicts early recurrence and poor prognosis in hepatocellular carcinoma[J]. Hepatology. 2008;48(4):1118-27.

3. lida M, lizuka N, Tsunedomi R, Tsutsui M, Yoshida S, Maeda Y, Tokuhisa Y, Sakamoto K, Yoshimura K, Tamesa T, Oka M. Overexpression of the RD RNA binding protein in hepatitis $C$ virus-related hepatocellular carcinoma[J]. Oncol Rep. 2012;28(2):728-34.

4. Qian HL, Chen SH, Peng XX. Significance of a novel fetal RNA-binding protein p62 expression in hepatocellular carcinoma][J]. Zhonghua Bing Li Xue Za Zhi. 2003;32(4):329-32.

5. Buckanovich RJ, Posner JB, Darnell RB. Nova, the paraneoplastic Ri antigen is homologous to an RNA-binding protein and is specifically expressed in the developing motor system[J]. Neuron. 1993;11(4):657-72.
6. Zhang YA, Zhu JM, Yin J, Tang WQ, Guo YM, Shen XZ, Liu TT. High expression of neuro-oncological ventral antigen 1 correlates with poor prognosis in hepatocellular carcinoma[J]. PLoS One. 2014;9(3):e90955.

7. Dredge BK, Darnell RB. Nova regulates GABA(A) receptor gamma2 alternative splicing via a distal downstream UCAU-rich intronic splicing enhancer[]]. Mol Cell Biol. 2003;23(13):4687-700.

8. Watanabe M, Maemura K, Kanbara K, Tamayama T, Hayasaki H. GABA and GABA receptors in the central nervous system and other organs[]]. Int Rev Cytol. 2002;213:1-47.

9. Minuk GY, Zhang M, Gong Y, Minuk L, Dienes H, Pettigrew N, Kew M, Lipschitz J, Sun D. Decreased hepatocyte membrane potential differences and GABAA-beta3 expression in human hepatocellular carcinoma[]]. Hepatology. 2007:45(3):735-45.

10. Liu Y, Li YH, Guo FJ, Wang JJ, Sun RL, Hu JY, Li GC. Gamma-aminobutyric acid promotes human hepatocellular carcinoma growth through overexpressed gamma-aminobutyric acid A receptor alpha 3 subunit[]]. World J Gastroenterol. 2008;14(47):7175-82.

11. Wang T, Huang W, Chen F. Baclofen, a GABAB receptor agonist, inhibits human hepatocellular carcinoma cell growth in vitro and in vivo[J]. Life Sci. 2008:82(9-10):536-41.

12. Richter L, de Graaf C, Sieghart W, Varagic Z, Morzinger M, de Esch IJ, Ecker GF, Ernst M. Diazepam-bound GABAA receptor models identify new benzodiazepine binding-site ligands[]]. Nat Chem Biol. 2012;8(5):455-64.

13. Johnston GA. GABAA receptor pharmacology[]]. Pharmacol Ther. 1996;69(3): 173-98.

14. Campagna-Slater $V$, Weaver DF. Molecular modelling of the GABAA ion channel protein[J]. J Mol Graph Model. 2007;25(5):721-30.

15. Khandheria BK, Seward JB, Oh JK, Freeman WK, Nichols BA, Sinak LJ, Miller FJ, Tajik AJ. Value and limitations of transesophageal echocardiography in assessment of mitral valve prostheses[]]. Circulation. 1991;83(6):1956-68.

16. Olsen RW, Sieghart W. GABA A receptors: subtypes provide diversity of function and pharmacology[]]. Neuropharmacology. 2009;56(1):141-8.

17. Maemura K, Shiraishi N, Sakagami K, Kawakami K, Inoue T, Murano M Watanabe M, Otsuki Y. Proliferative effects of gamma-aminobutyric acid on the gastric cancer cell line are associated with extracellular signal-regulated kinase 1/2 activation[J]. J Gastroenterol Hepatol. 2009;24(4):688-96.

18. Sun D, Gong Y, Kojima H, Wang G, Ravinsky E, Zhang M, Minuk GY Increasing cell membrane potential and GABAergic activity inhibits malignant hepatocyte growth[J]. Am J Physiol Gastrointest Liver Physiol. 2003;285(1):G12-9.

19. Erlitzki R, Gong $Y$, Zhang $M$, Minuk G. Identification of gamma-aminobutyric acid receptor subunit types in human and rat liver[]]. Am J Physiol Gastrointest Liver Physiol. 2000;279(4):G733-9.

20. Buckanovich RJ, Yang YY, Darnell RB. The onconeural antigen Nova-1 is a neuron-specific RNA-binding protein, the activity of which is inhibited by paraneoplastic antibodies[J]. J Neurosci. 1996;16(3):1114-22.

21. Teplova M, Malinina L, Darnell JC, Song J, Lu M, Abagyan R, Musunuru K, Teplov A, Burley SK, Darnell RB, Patel DJ. Protein-RNA and protein-protein recognition by dual KH1/2 domains of the neuronal splicing factor Nova1[J]. Structure. 2011;19(7):930-44.

\section{Submit your next manuscript to BioMed Central and we will help you at every step:}

- We accept pre-submission inquiries

- Our selector tool helps you to find the most relevant journal

- We provide round the clock customer support

- Convenient online submission

- Thorough peer review

- Inclusion in PubMed and all major indexing services

- Maximum visibility for your research

Submit your manuscript at www.biomedcentral.com/submit
) Biomed Central 